PENGARUH NON PERFORMANCE LOAN (NPL) DAN LOAN DEPOSITO RATIO (LDR) TERHADAP RETURN ON ASSET (ROA) PADA PT. BANK RAKYAT INDONESIA (PERSERO), TBK

\title{
THE EFFECT OF NON PERFORMANCE LOAN (NPL) AND LOAN DEPOSIT RATIO (LDR) ON RETURN ON ASSET (ROA) IN PT. BANK RAKYAT INDONESIA (PERSERO), TBK
}

\author{
Agung Rahmat Ilahi'); Karona Cahya Susena'); Wagini ${ }^{3)}$ \\ 1,2) Department of Management, Faculty of Economic, Universitas Dehasen Bengkulu \\ 3) Department of Accounting Faculty of Economic, Universitas Dehasen Bengkulu \\ Email: wagini980@gmail.com
}

\begin{abstract}
How to Cite :
Ilahi, A. R., et.al (2021). The Effect Of Non Performance Loan (NPL) and Loan Deposit Ratio (LDR) On Return On Asset (ROA) In PT. Bank Rakyat Indonesia (PERSERO), TBK. Bima Journal : Business, Management and Accounting Journal, 2 (1).DOI: https://doi.org/10.37638/bima.2.1.83-96
\end{abstract}

\section{ARTICLE HISTORY \\ Received [03 April 2021] \\ Revised [15 April 2021] \\ Accepted [1 June 2021] \\ KEYWORDS \\ Non Performance Loans \\ (NPL), Loan Deposit Ratio (LDR), Return On Asset (ROA)}

This is an open access article under the $C C-B Y-S A$ license

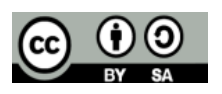

\begin{abstract}
ABSTRAK
Tujuan penelitian ini adalah untuk mengetahui pengaruh Non Performance Loan (NPL) dan Loan Deposito Ratio (LDR) terhadap Return on Asset (ROA) Pada PT. Bank Rakyat Indonesia (Persero), Tbk Sampel dalam penelitian ini adalah laporan keuangan pada PT. Bank Rakyat Indonesia (Persero), Tbk periode 2010 sampai 2019 Metode pengumpulan data menggunakan metode dokumentasi Analisis data yang digunakan adalah regresi linier berganda, koefesien determinasi dan uji hipotesis. Dari perhitungan persamaan regresi linier berganda dapat diketahui bahwa hasil uji regresi : $Y$ $=14,944-1,072 X_{1}-0,099 X_{2}$. Koefesien determinasi yang diperoleh sebesar 0,846. Hal ini berarti bahwa $X_{1}$ (Non Performance Loan (NPL)) dan $X_{2}$ (Loan Deposito Ratio (LDR)) berpengaruh terhadap Return on Asset (ROA) (Y) sebesar 84,6\% sedangkan sisanya (100\% - 84,6\% = 15,4\%) dipengaruhi oleh variabel-variabel lainnya yang tidak diteliti dalam penelitian ini. Hasil pengujian uji $t$ menunjukkan adanya pengaruh yang signifikan antara NPL dan LDR terhadap Return on Asset (ROA) (Y) pada PT. Bank Rakyat Indonesia (Persero), Tbk secara parsial atau terpisah Hasil pengujian uji $F$, menunjukkan adanya pengaruh yang signifikan antara NPL dan LDR terhadap Return on Asset (ROA) (Y) pada PT. Bank Rakyat Indonesia (Persero), Tbk secara simultan atau bersama-sama.
\end{abstract}




\begin{abstract}
The purpose of this study was to determine the effect of Non Performance Loans (NPL) and Loan Deposit Ratio (LDR) on Return on Assets (ROA) at PT. Bank Rakyat Indonesia (Persero), Tbk. The sample in this study is the financial statements at PT. Bank Rakyat Indonesia (Persero), Tbk for the period 2010 to 2019 The data collection method uses the documentation method. The data analysis used is multiple linear regression, coefficient from the calculation of the multiple linear regression equation, it can be seen that the results of the regression test: $Y=14.944-1.072 X 1$ $0.099 \times 2$. The coefficient of determination obtained is 0.846 . This means that X1 (Non Performance Loan (NPL)) and X2 (Loan Deposit Ratio (LDR)) have an effect on Return on Assets (ROA) (Y) by $84.6 \%$ while the rest $(100 \%-84.6 \%=15.4 \%)$ is influenced by other variables not examined in this study. The results of the $t$ test show that there is a significant effect between NPL and LDR on Return on Assets (ROA) (Y) at PT. Bank Rakyat Indonesia (Persero), Tbk partially or separately The results of the F test show that there is a significant influence between NPL and LDR on Return on Assets (ROA) (Y) at PT. Bank Rakyat Indonesia (Persero), Tbk simultaneously or collectively.of determination and hypothesis testing.
\end{abstract}

\title{
PENDAHULUAN
}

Bank Memberikan manfaaat bagi Perekonomian secara keseluruhan. Berbagai manfaat berupa mekanisme alokasi sumber-sumber dana secara efektif dan efisien. Ini yang dinamakan fungsi intermediasi yang dapat dikatakan bahwa bank merupakan penyalur dana dari unit-unit ekonomi yang mempunyai kelebihan dana kepada unit-unit yang kekurangan dana. Dengan proses intermediasi seperti ini, bank sebagai lembaga intermediasi berperan penting dalam mobilisasi danadana masyarakat untuk diputar sebagai salah satu sumber pembiayaan utama bagi dunia usaha, baik untuk investasi maupun produksi, dalam rangka mendorong pertumbuhan ekonomi.

Bank berfungsi sebagai media dalam mentransmisikan kebijakan moneter yang dilakukan bank sentral karena kebijakan moneter sendiri bertujuan untuk menjaga stabilitas harga dan pertumbuhan ekonomi (Kasmir, 2015).

Karena manfaatnya yang begitu penting bagi perekonomian, maka setiap negara berupaya agar perbankan selalu berada dalam kondisi yang sehat, aman dan stabil. Perbankan merupakan industri yang syarat dengan risiko, terutama karena melibatkan pengelolaan uang masyarakat dan diputar dalam bentuk berbagai investasi, seperti pemberian kredit, pembelian surat- surat berharga dan penanaman dana lainya. Kondisi perbankan di Indonesia selama beberapa tahun

84 | Agung Rahmat Ilahi; et.al (2021); The Effect Of Non Performance Loan (NPL) and Loan Deposit Ratio... 
ini penuh dinamika bagi industri perbankan nasional. Ditengah beratnya tantangan yang dihadapi, bank pada umumnya mampu mempertahankan kinerja yang positif. Namun demikian, fungsi intermediasi masih terkendala akibat perubahan kondisi perekonomian yang kurang menguntungkan.

Menurut Suhardjono, 2016, Non Performing loan (NPL) adalah salah satu cara untuk menilai kinerja fungsi bank dalam mengelola bisnisnya. NPL yang tinggi menyebabkan timbulnya masalah likuiditas (ketidakmampuan membayar pihak ketiga), rentabilitas (utang tidak bisa ditagih), ataupun solvabilitas (modal berkurang).

Rasio kredit yang diberikan terhadap dana pihak ketiga yang diterima oleh bank yang bersangkutan disebut Loan to Deposit Ratio (LDR). Besarnya LDR akan berpengaruh terhadap laba melalui penciptaan kredit. LDR juga mempunyai peranan yang sangat penting sebagai indikator yang menunjukkan tingkat ekspansi kredit yang dilakukan bank sehingga LDR dapat juga digunakan untuk mengukur berjalan tidaknya suatu fungsi intermediasi bank. LDR yang tinggi mengindikasikan adanya penanaman dana dari pihak ketiga yang besar ke dalam bentuk kredit Dendawijaya, 2017.

Rasio Return on Asset (ROA) merupakan indikator penting dari laporan keuangan yang memiliki berbagai kegunaan. Rasio ROA digunakan untuk mengukur kemampuan manajemen bank dalam memperoleh keuntungan (laba) secara keseluruhan, semakin besar ROA suatu bank semakin besar pula tingkat keuntungan yang dicapai bank tersebut dan semakin baik pula posisi bank tersebut dari segi penggunaan aktiva. Laba pada umumnya dipakai sebagai suatu dasar pengambilan keputusan investasi, dan prediksi untuk meramalkan perubahan laba yang akan datang. Investor mengharapkan dana yang di investasikan ke dalam perusahaan akan memperoleh tingkat pengembalian yang tinggi sehingga laba yang diperoleh jadi tinggi pula Dendawijaya, 2017.

\section{LANDASAN TEORI}

\section{Bank}

Menurut Kasmir, 2015 bank merupakan lembaga keuangan yang kegiatan usahanya adalah menghimpun dana dari masyarakat dan menyalurkan kembali dana tersebut kemasyarakat serta memberikan jasa bank lainnya. Kemudian pengertian bank menurut Undang-Undang Nomor 10 tahun 1998 bank merupakan badan usaha yang menghimpun dana dari masyarakat dalam bentuk simpanan dan menyalurkannya ke masyarakat dalam bentuk kredit atau bentuk-bentuk lainnya dalam rangka meningkatkan taraf hidup rakyat banyak.

Menurut Martono, 2015 bank merupakan salah satu badan usah lembaga yang bertujuan memberikan kredit, baik dengan alat pembayaran sendiri, dengan uang yang diperolehnya dari orang lain dengan jalan mengedarkan alat-alat pembayaran baru berupa uang giral. 


\section{Jenis Bank}

Menurut Martono, 2015 adapun jenis perbankan ini dapat ditinjau dari berbagai segi antara lain:

1. Dilihat dari segi fungsinya.

a. Bank Umum

Bank umum menurut Peraturan Bank Indonesia No. 9/7/PBI/2007 adalah bank yang melaksanakan kegiatan usaha secara konvensional dan atau berdasarkan prinsip syariah yang dalam kegiatannya memberikan jasa dalam lalu lintas pembayaran.

b. Bank Perkreditan Rakyat

Bank Perkreditan Rakyat adalah bank yang melaksanakan kegiatan usaha secara konvensional atau berdasarkan prinsip syariah yang dalam kegiatannya tidak memberikan jasa dalam lalu lintas pembayaran. Kegiatan BPR jauh lebih sempit jika dibandingkan dengan kegiatan bank umum.

c. Bank Sentral

Fungsi bank sentral di Indonesia di pegang oleh Bank Indonesia(Bl), Bank Sentral tidak termasuk kedalam undang- undang Republik Indonesia No.10 tahun 1998 tentang perbankan hal ini dikarenakan pada prinsipnya Bank Indonesia merupakan lembaga Negara yang turut berfungsi mengawasi pelaksanaan Undang-Undang tersebut, yaitu dalam kapasitasnya selaku pembinaan dan pengawas bank. Bank Sentral bersifat tidak komersial seperti halnya Bank Umum dan Bank Perkreditan Rakyat.

2. Dilihat dari Segi Kepemilikan

a. Bank Milik pemerintah

Akte maupun modalnya dimiliki oleh pemerintah sehingga seluruh keuntungan bank ini dimiliki oleh pemerintah pula. Contoh bank milik pemerintah, antara lain .Bank Negara Indonesia 46 (BNI), Bank Rakyat Indonesia (BRI), Bank Tabungan Negara(BTN).

b. Bank milik swasta nasional

Bank jenis ini seluruh atau sebagian besamya dimiliki oleh swasta nasional serta akte pendiriannya pun didirikan oleh swasta, begitu pula pembagian keuntungannya untuk keuntungan swasta pula. Contoh bank swasta nasional antara lain:Bank Muamalat, Bank Central Asia, Bank Bumi Putra, Bank Danamon, Bank Duta.

c. Bank milik Asing

Bank jenis ini merupakan cabang dari bank yang ada di luar negeri, baik milik swasta asing atau pemerintah asing. Contoh Bank Asing antara lain: Deutsche

86 | Agung Rahmat Ilahi; et.al (2021); The Effect Of Non Performance Loan (NPL) and Loan Deposit Ratio... 
Bank, American Express Bank, Bank of America, Bank of Tokyo, Bangkok Bank, Hongkong Bank.

d. Bank Milik Campuran

Kepemilikan saham bank campuran dimiliki oleh pihak asing dan pihak swasta nasional. Kepemilikan sahamnya secara mayoritas dipegang oleh warga negara Indonesia. Contoh bank campuran antara lain: Bank Sakura Swadarma Bank Finconesia, Mitsubishi Buana Bank, Interpacific Bank.

e. Bank Milik Koperasi

Kepemilikan saham-saham bank ini dimiliki oleh perusahaan yang berbadan hukum koperasi. Sebagai contoh: Bank Umum Koperasi Indonesia.

3. Dilihat dari Segi Status

a. Bank Devisa

Merupakan bank yang dapat melaksanakan transaksi ke luar negeri atau yang behubungan dengan mata uang asing secara keseluruhan, misalnya transfer keluar negeri, inkaso keluar negeri, travellers cheque, pembukaan dan pembayaran Letter of Credit dan transaksi lainnya. Persyaratan untuk menjadi bank devisa ini ditentukan oleh Bank Indonesia.

b. Bank Non Devisa

Merupakan bank yang belum mempunyai izin untuk melaksanakan transaksi sebagai bank devisa sehingga tidak dapat melaksanakan transaksi seperti halnya Bank Devisa. Jadi Bank Non Devisa merupakan kebalikan daripada Bank Devisa, transaksi yang dilakukan masih dalam batas-batas Negara.

4. Dilihat dari segi menentukan harga

a. Bank yang berdasarkan prinsip konvensional Mayoritas bank yang berkembang di Indonesia dewasa ini adalah bank yang berorientasi pada prinsip konvensional.

b. Bank yang berdasarkan prinsip syariah

Bagi bank yang berdasarkan prinsip syariah dalam penentuan harga produknya sangat berbeda dengan bank yang berdasarkan prinsip konvensional.

\section{Laporan Keuangan}

Menurut Fahmi, 2016 laporan keuangan merupakan alat yang sangat penting untuk memperoleh informasi sehubugnan dengan posisi keuangan dan hasil-hasil yang telah dicapai oleh perusahaan yang bersangkutan. Dengan begitu laporan keuangan diharapkan akan membantu bagi para pengguna untuk membuat keptusanekonomi yang bersifat finansial.

Kasmir, 2015 berpendapat bahwa laporan keuangan adalah laporan yang menunjukkan kondisi keuangan perusahaan pada saat ini atau dalam suatu 
periode tertentu. Dengan adanya laporan keuangan maka dapat dilihat kondisi keuangan perusahaan pada saat periode tersebut, apakah peruahaan mengalami kemajuan atau kemunduran. Sehingga dengan laporan keuangan tersebut para investor dapat mengetahui perkembangan dana yang mereka investasikan.

\section{Rasio Keuangan Bank}

Rasio keuangan merupakan suatu alat analisis yang dapat digunakan oleh perusahaan dalam menjalankan kegiatan usahanya.

Menuruh Fahmi, 2016 rasio keuangan atau financial ratio ini sangat penting gunanya untuk melakukan analisa terhadap kondisi keuangan perusahaan. Bagi investor jangka pendek dan menengah pada umumnya lebih banyak tertarik kepada kondisi keuangan jangka pendek dan kemampuan perusahaan untuk membayar dividen yang memadai. Informasi tersebut dapat diketahui dengan cara yang lebih sederhana yaitu dengan menghitung rasio-rasio keuangan yang sesuai dengan keinginan.

Sedangkan menurut Kasmir, 2015 rasio keuangan merupakan kegiatan membandingkan angka-angka yang ada dalam laporan keuangan decan cara membagi satu angka dengan angka lainnya. Perbandingan dapat dilakukan antara satu komponen dengan komponen dalam satu laporan keuangan atau antarkomponen yang ada diantara laporan keuangan. Kemudian angka yang diperbandingkan dapat berupa angka-angka dalam satu periode maupun beberapa periode.

\section{NPL (Non Performing Loan)}

Non Performing Loan (NPL) merupakan rasio keuangan yang menunjukkan risiko kredit yang dihadapi bank akibat pemberian kredit dan investasi dana bank pada portofolio yang berbeda. Menurut Kuncoro dan Suhardjono, 2016 risiko kredit/default risk ini dapat terjadi akibat kegagalan atau ketidakmampuan nasabah dalam mengembalikan jumlah pinjaman yang diterima dari bank beserta bunganya sesuai dengan jangka waktu yang telah dijadwalkan.

Menurut Darmawi, 2017 pengertian Non Performing Loan (NPL) adalah"Salah satu pengukuran dari rasio risiko usaha bank yang menunjukkan besarnya risiko kredit bermasalah yang ada pada suatu bank. Kredit bermasalah diakibatkan oleh ketidak lancaran pembayaran pokok pinjaman dan bunga yang secara langsung dapat menurunkan kinerja bank dan menyebabkan bank tidak efisien.

Setiap bank harus mengetahui tingkat kolektibilitas dari kredit yang diberikan. Hal ini diperlukan untuk mengetahui besarnya cadangan minimum pemghapusan aktiva produktif yang harus disediakan oleh bank untuk menutup kemungkinan kerugian yang terjadi. Non Performing Loan (NPL) merupakan rasio yang menunjukkan rasio kredit bermasalah terhadap total kredit. Perhitungan rasio Non Performing Loan (NPL) menurut Manurung \& Rahardja, 2014 adalah sebagai berikut:

88 | Agung Rahmat llahi; et.al (2021); The Effect Of Non Performance Loan (NPL) and Loan Deposit Ratio... 


$$
\text { NPL }=\frac{\text { Kredit Bermasalah }}{\text { Total Kredit }} \times 100 \%
$$

Kredit masalah adalah total keseluruhan kredit yang berada dalam kolektibilitas kredit kurang lancar, diragukan dan macet. Sedangkan total kredit adalah keseluruhan penyediaan uang atau tagihan yang dapat dipersamakan dengan itu berdasarkan persetujuan atau kesepakatan pinjam meminjam dengan debitur yang mewajibkan debitur untuk melunasi hutangnya setelah jangka waktu tertentu beserta bunganya Manurung \& Rahardja, 2014.

\section{LDR (Loan to Deposit Ratio)}

Rasio likuiditas adalah rasio yang digunakan untuk mengukur kemampuan bank dalam memenuhi kewajiban-kewajiban jangka pendeknya atau kewajiban yang sudah jatuh tempo. Salah satu rasio likuiditas yang sering digunakan dalam menilai kinerja suatu bank adalah Loan to Deposit Ratio (LDR). Menurut Dendawijaya, 2017, LDR adalah rasio antara seluruh jumlah kredit yang diberikan bank dengan dana yang diterima oleh bank. Loan to Deposit Ratio (LDR) adalah rasio kredit yang diberikan kepada pihak ketiga dalam Rupiah dan valuta asing, tidak termasuk kredit kepada bank lain, terhadap Dana Pihak Ketiga (DPK) yang mencakup giro, tabungan, dan deposito dalam Rupiah dan valuta asing, tidak termasuk dana antar bank. Rasio LDR menyatakan seberapa jauh kemampuan bank dalam membayar kembali penarikan dana yang dilakukan deposan dengan mengandalkan kredit yang diberikan sebagai sumber likuiditasnya. Dengan kata lain, seberapa jauh pemberian kredit kepada nasabah dapat mengimbangi kewajiban bank untuk segera memenuhi permintaan deposan yang ingin menarik kembali uangnya yang telah digunakan oleh bank untuk memberikan kredit. Berdasarkan SE BI No.13/30/DPNP tanggal 16 Desember 2015 perhitungan LDR sebagai berikut:

$$
\text { LDR }=\frac{\text { Total Kredit }}{\text { Dana Pihak Ketiga }}
$$

Batas bawah yang ditetapkan oleh Bank Indonesia untuk rasio LDR adalah 78\%, artinya jika bank umum menyalurkan kredit di bawah angka tersebut maka bank dianggap masih kurang efisien dalam penyaluran kredit. Namun apabila jumlah penyaluran kredit melewati batas atas yakni 100\%, maka bank tersebut dianggap terlalu agresif sehingga dapat meningkatkan eksposur risiko yang dihadapi. Oleh karena itu, angka LDR bank harus dijaga di kisaran ideal yang sudah ditetapkan.

\section{ROA (Return on Asset)}


ROA atau sering diterjemahkan ke dalam Bahasa Indonesia sebagai rentabilitas ekonomi mengukur kemampuan perusahaan dalam menghasilkan laba pada masa lalu. Analisis mengenai ROA kemudian bisa diproyeksikan ke masa depan untuk melihat kemampuan perusahaan dalam menghasilkan laba pada masa mendatang. ROA mengukur kemampuan perusahaan menghasilkan laba dengan menggunakan total asset (kekayaan) yang dipunyai perusahaan setelah disesuaikan dengan biayabiaya untuk mendanai aset tersebut Hanafi \& Halim, 2017.

ROA adalah alat untuk menganalisis atau mengukur tingkat efisiensi usaha dan profitabilitas yang dicapai oleh bank yang bersangkutan. ROA digunakan untuk mengukur kemampuan manajemen bank dalam memperoleh (laba) secara keseluruhan. Menurut Kuncoro \& Suhardjono, 2016.

Return On Asset (ROA) adalah rasio keuntungan bersih sebelum pajak untuk menilai seberapa besar tingkat pengembalian dari asset yang dimiliki oleh perusahaan. Perhitungan Return On Asset (ROA) menurut Pandia (2014:71) dapat dihitung dengan cara:

$$
\text { ROA }=\frac{\text { Laba Sebelum Pajak }}{\text { Total Asset }}
$$

Standar yang ditetapkan oleh Bank Indonesia untuk Return On Assets (ROA) adalah sebesar 1,5\% sesuai dengan Surat Edaran Bank Indonesia No. 6/10/PBI/2004. Return On Assets (ROA) suatu bank dikatakan sehat jika bank memiliki Return On Assets (ROA) lebih besar dari 1,5\%. Semakin besar Return On Assets (ROA) suatu bank, semakin besar pula tingkat keuntungan yang dicapai bank tersebut dan semakin baik pula posisi bank tersebut dari segi penggunaan asset (Dendawijaya 2017:118).

\section{METODE PENELITIAN}

\section{Jenis Penelitian}

Jenis penelitian dalam penelitian ini adalah penelitian asosiatif. Menurut Sugiyono, 2017 penelitian asosiatif adalah penelitian yang bertujuan untuk mengetahui pengaruh variable independen terhadap variable dependen. Sifat penelitian asosiatif ini dibuktikan dengan adanya variable independen atau variable X (NPL dan $L D R$ ) terhadap variabel dependen yaitu Variabel Y berupa ROA.

\section{Metode Pengambilan Sampel}

Populasi menurut Sugiyono, 2017 adalah objek atau subjek yang mempunyai kualitas dan karakteristik tertentu yang ditetapkan oleh peneliti untuk mempelajari dan kemudian ditarik kesimpulannya. Populasi terdiri dari manusia atau orang, file atau dokumen yang dapat dipandang sebagai objek penelitian

90 | Agung Rahmat Ilahi; et.al (2021); The Effect Of Non Performance Loan (NPL) and Loan Deposit Ratio... 
Sugiyono, 2017. Populasi dalam penelitian ini adalah laporan keuangan pada PT. Bank Rakyat Indonesia (Persero), Tbk dari tahun 2010 sampai 2019.

Sampel penelitian merupakan suatu langkah untuk menentukan besarnya sample yang akan diambil untuk melaksanakan suatu penelitian. Menurut Sugiyono, 2017 adalah bagian dari jumlah dan karakteristik yang dimiliki oleh populasi tersebut. Sampel dalam penelitian ini adalah laporan keuangan pada PT. Bank Rakyat Indonesia (Persero), Tbk periode 2010 sampai 2019. Teknik pengambilan sampel dalam penelitian ini dengan menggunakan teknik sampling jenuh, sampling jenuh adalah teknik pengambilan sampel apabila semua populasi digunakan sebagai sampel.

\section{Metode Analisis}

1. Pengukuran Variabel Penelitian

a. NPL (Non Performing Loan)

Perhitungan rasio Non Performing Loan (NPL) menurut Manurung \& Rahardja, 2014 adalah sebagai berikut:

$$
\text { NPL }=\frac{\text { Kredit Bermasalah }}{\text { Total Kredit }} \times 100 \%
$$

b. LDR (Loan to Deposit Ratio)

Berdasarkan SE BI No.13/30/DPNP tanggal 16 Desember 2015 perhitungan LDR sebagai berikut:

$$
\text { LDR }=\frac{\text { Total Kredit }}{\text { Dana Pihak Ketiga }}
$$

c. ROA (Return on Asset)

Perhitungan Return On Asset (ROA) Pandia, 2014 dapat dihitung dengan cara:

$$
\text { ROA }=\frac{\text { Laba Sebelum Pajak }}{\text { Total Asset }}
$$

2. Regresi Linear Berganda

Metode analisis untuk mengetahui variabel independen yang mempengaruhi secara signifikan terhadap ROA pada PT. Bank Rakyat Indonesia (Persero), Tbk yaitu, LDR dan NPL digunakan persamaan umum regresi linier berganda atas dua variabel bebas terhadap variabel tidak bebas umum regresi berganda. Rumus umum dari regresi linier berganda menurut Husein, 2014 yaitu :

$Y=a+b_{1} X_{1}+b_{2} X_{2}+b_{3} X_{3}+e$

Dimana:

$\mathrm{Y}=\mathrm{ROA}$

a $=$ Konstanta

$\mathrm{b}_{1,2}=$ Penaksiran Koefisien regresi

$\mathrm{X} 1=\mathrm{NPL}$

$\mathrm{X} 2=\mathrm{LDR}$

$\mathrm{e} \quad=$ Variabel Residual (tingkat kesalahan) 
3. Koefisien Determinasi

Perhitungan determinasi dapat dilakukan sebagai berikut :

$\mathrm{KD}=\mathrm{r}^{2} \times 100 \%$

$\mathrm{R}=$ Korelasi koefisien product moment

4. Pengujian Hipotesis

a. Ujit

Uji t pada dasarnya menunjukkan seberapa jauh pengaruh satu variabel bebas secara individual dalam menerangkan variasi variabel terikat.

Formula hipotesis:

1. $\mathrm{H}_{01}: \mathrm{bi}=0$,artinya NPL tidak berpengaruh secara signifikan terhadap ROA

$\mathrm{H}_{\mathrm{a} 1}: \mathrm{bi} \neq 0$, artinya NPL berpengaruh secara signifikan terhadap ROA.

2. H02:bi $=0$,artinya LDR tidak berpengaruh secara signifikan terhadap ROA

$\mathrm{H}_{\mathrm{a} 2}$ : bi $\neq 0$, artinya LDR berpengaruh secara signifikan terhadap ROA. Untuk menguji hipotesis tersebut digunakan statistik $\mathrm{t}$ yang dihitung dengan cara sebagai berikut :

$\mathrm{t}=\frac{\mathrm{b}}{\mathrm{Sb}}$

Sugiyono, 2017

Dimana b adalah nilai parameter dan Sb adalah standart error dari b. Standart error dari masing-masing paramater dihitung dari akar varians masing-masing. Untuk mengetahui kebenaran hipotesis digunakan kriteria bila t hitung $>\mathrm{t}$ tabel maka Ho ditolak dan Ha diterima, artinya ada pengaruh antara variabel bebas terhadap variabel terikat dengan derajat keyakinan yang digunakan sebesar a

$=5 \%$, begitu pula sebaliknya bila $\mathrm{t}$ hitung $<\mathrm{t}$ tabel maka menerima Ho dan menolak Ha artinya tidak ada pengaruh antara variabel bebas terhadap variabel terikat.

b. Uji F

Uji F dilakukan untuk mengetahui pengaruh variabel bebas secara bersamasama terhadap variabel terikat. aRumusan hipotesis yang diuji: Ho : b1 = b2 = b 0, berarti secara bersama-sama NPL, LDR tidak berpengaruh terhadap ROA.

$\mathrm{Ha}: \mathrm{b} 1 \neq \mathrm{b} 2 \neq \mathrm{b} 0$, berarti secara secara bersama-sama NPL, LDR berpengaruh terhadap ROA.

Untuk menguji kebenaran hipotesis alternatif dilakukan uji $\mathrm{F}$ dengan rumus sebagai berikut:

$$
F=\frac{R^{2} / k}{\left(1-R^{2}\right) /(n-k-1}
$$

92 | Agung Rahmat llahi; et.al (2021); The Effect Of Non Performance Loan (NPL) and Loan Deposit Ratio... 
Sugiyono, 2017

Bila $\mathrm{F}$ hitung $>\mathrm{F}$ tabel maka Ho ditolak dan Ha diterima, artinya semua variabel bebas secara bersama-sama merupakan penjelas yang signifikan terhadap variabel terikat. Bila $\mathrm{F}$ hitung $<\mathrm{F}$ tabel maka Ho diterima dan $\mathrm{Ha}$ ditolak, artinya semua variabel bebas secara bersama-sama bukan merupakan variabel penjelas.

\section{HASIL DAN PEMBAHASAN}

\section{Pembahasan}

\section{Pengaruh Non Performance Loan (NPL) ) terhadap Return on Asset (ROA)}

Hasil penelitian menunjukkan arah regresi memiliki nilai negatif artinya Non Performance Loan (NPL) memiliki pengaruh negatif terhadap Return on Asset (ROA), artinya semakin tinggi Non Performance Loan (NPL) maka Return on Asset (ROA) akan semakin menurun. Dibuktikan dengan hasil nilai signifikansi diperoleh sebesar 0,004 < 0,05 artinya adanya pengaruh yang signifikan dari Loan Deposito Ratio (LDR) terhadap Return on Asset (ROA). Artinya bahwa setiap adanya kenaikan resiko kredit bermasalah maka akan menurunkan tingkat perolehan laba suatu bank.

Hasil penelitian menunjukkan bahwa bank telah mampu menurunkan nilai NPL dari tahun ke tahun sehingga mampu meningkatkan ROA. Nilai NPL yang kecil akan berpotensi pada peningkatan laba, karena semakin kecil NPL maka dapat dikatakan manajemen bank telah mampu mengelola kredit bermasalah yang diberikan oleh bank. Artinya, semakin rendah rasio ini maka kondisi bermasalah akan semakin kecil yang diakibatkan oleh pengembalian kredit macet, semakin tinggi rasio ini maka akan semakin buruk kualitas kredit bank yang menyebabkan jumlah kredit bermasalah semakin besar maka kemungkinan suatu bank dalam kondisi bermasalah semakin besar yaitu kerugian yang diakibatkan tingkat pengembalian kredit macet atau kredit bermasalah.

Kredit bermasalah adalah kredit yang memiliki kualitas dalam perhatian khusus (special mention), kurang lancar (substandard), diragukan (doubtful), dan macet (loss). Rasio ini menunjukkan kualitas aktiva kredit yang jika kolektibilitasnya kurang lancar, diragukan dan macet dari total kredit secara keseluruhan maka bank tersebut menghadapi kredit bermasalah. Semakin tinggi rasio maka semakin besar pula jumlah kredit yang tak tertagih dan berakibat pada penurunan pendapatan bank yang berdampak pada perolehan laba.

Hasil penelitian ini sejalan dengan penelitian yang dilakukan oleh Ardiansyah \& Mawardi, 2017 yang menyimpulkan bahwa NPL berpengaruh negatif dan signifikan terhadap ROA. Semakin kecil LDR yang diperoleh oleh suatu bank 
maka akan meningkatkan ROA nya. Bank yang mampu menciptakan LDR lebih kecil dari standar LDR maksimal yang ditetapkan oleh Bank Indonesia yaitu 5\% dikatakan bahwa bank telah mampu mencegah terjadinya kredit macet sehingga mampu meningkatkan perolehan laba.

\section{Pengaruh LDR (Loan Deposito Ratio) terhadap ROA (Return on Asset)}

Berdasarkan hasil penelitian dapat dilihat bahwa pengujian hipotesis diperoleh nilai signifikan sebesar 0,001, karena nilai signifikan berada dibawah 0,05 maka dapat disimpulkan bahwa LDR berpengaruh signifikan terhadap ROA PT. Bank Rakyat Indonesia, Tbk dengan koefisien regresi LDR sebesar 0,099 . Dalam penelitian ini, LDR menunjukkan pengaruh yang negatif yang artinya bahwa peningkatan LDR akan menurunkan ROA. Hal ini menggambarkan bahwa setiap adanya peningkatan pengembalian dana kepada pihak ketiga maka akan menurunkan tingkat perolehan laba pada bank tersebut.

Hasil penelitian ini menunjukkan bahwa semakin rendah LDR menunjukkan kurangnya efektivitas bank dalam menyalurkan kredit. LDR yang rendah menunjukkan bank belum sepenuhnya mampu mengoptimalkan penggunaan dana masyarakat untuk melakukan ekspansi kredit. LDR yang berada di bawah target dan limitnya, maka akan dikatakan bahwa bank memelihara alat likuid yang berlebihan dan ini akan menimbulkan tekanan terhadap pendapatan bank berupa tingginya biaya pemeliharaan kas yang menganggur (Kuncoro, 2002). Sehingga dapat dikatakan bahwa bank tersebut tidak menjalankan fungsinya sebagai intermediasi dengan baik. Semakin tinggi LDR maka laba yang diperoleh oleh bank tersebut akan meningkat (dengan asumsi bahwa bank tersebut mampu menyalurkan kreditnya dengan efektif sehingga diharapkan jumlah kredit macetnya rendah).

Namun di sisi lain, penyaluran kredit yang berlebihan akan meningkatkan risiko yang dihadapi bank. Maka dari itu, bank juga perlu selektif dalam pemberian kredit karena selain memberikan keuntungan berupa pendapatan bunga, penyaluran kredit yang tidak tepat juga dapat memicu adanya kredit bermasalah.

Semakin besarnya penyaluran dana dalam bentuk kredit dibandingkan dengan deposit atau simpanan masyarakat pada suatu bank membawa konsekuensi semakin besarnya risiko yang harus ditanggung oleh bank yang bersangkutan, maka bank harus bisa menyeimbangkan antara penerimaan dari pihak ketiga dengan jumlah dana yang disalurkan kepada nasabah.

94 | Agung Rahmat Ilahi; et.al (2021); The Effect Of Non Performance Loan (NPL) and Loan Deposit Ratio... 


\section{KESIMPULAN DAN SARAN}

\section{Kesimpulan}

1. Hasil uji regresi : $Y=14,944-1,072 X_{1}-0,099 X_{2}$

2. Koefesien determinasi yang diperoleh sebesar 0,846. Hal ini berarti bahwa $X_{1}$ (Non Performance Loan (NPL)) dan $\mathrm{X}_{2}$ (Loan Deposito Ratio (LDR) ) berpengaruh terhadap Return on Asset (ROA) (Y) sebesar 84,6\% sedangkan sisanya (100\% $84,6 \%=15,4 \%)$ merupakan variabel- variabel lainnya yang tidak diteliti dalam penelitian ini.

3. Pengujian menggunakan uji t menunjukkan adanya pengaruh yang signifikan antara NPL dan LDR terhadap ROA pada PT. Bank Rakyat Indonesia (Persero), Tbk secara parsial atau terpisah

4. Hasil pengujian uji $F$, menunjukkan adanya pengaruh yang signifikan antara NPL dan LDR terhadap ROA pada PT. Bank Rakyat Indonesia (Persero), Tbk secara simultan atau bersama-sama.

\section{Saran}

1. Diharapkan kepada PT. Bank Rakyat Indonesia (Persero), Tbk lebih memperhatikan pinjaman atau kredit yang diberikan kepada nasabah, banyaknya nasabah yang menunggak berakibat buruk terhadap keuangan perusahaan terutama pada aktiva produktif.

2. kinerja perusahaan akan semakin meningkat jika PT. Bank Rakyat Indonesia (Persero), Tbk dapat mengoptimalkan pengelolaan permodalan yang tersedia sehingga meningkatkan laba dan menekan kewajiban-kewajiban.

\section{DAFTAR PUSTAKA}

Ardiansyah, R., \& Mawardi, W. (2017). Analisis Pengaruh Capital Adequacy Ratio, Loan To Deposit Ratio, Bopo, Dannet Interest Marginterhadap Kinerja Keuangan Bank. Jurnal Manajemen, 6(4), 1-12.

Darmawi, H. (2017). Manajemen Perbankan. Bumi Aksara.

Dendawijaya, L. (2017). Manajemen Perbankan (2nd ed.). Ghalia Indonesia.

Fahmi, I. (2016). Bank dan Lembaga Keuangan Lainnya Teori dan Aplikasi. Alfabeta.

Hanafi, M. M., \& Halim, A. (2017). Analisis Laporan Keuangan. Liberty.

Husein, U. (2014). Metode Penelitian untuk Skripsi dan Tesis Bisnis. PT.Raja Grafindo Persada.

Kasmir. (2015). Bank dan Lembaga Keuangan Lainnya. PT Raja Grafindo Persada.

Kuncoro, \& Suhardjono. (2016). Manajemen Perbankan (Teori dan Aplikasi) (1st ed.). BPFE UII. 
Manurung, M., \& Rahardja, P. (2014). Teori Ekonomi Makro. FE UI.

Martono. (2015). Bank dan Lembaga Keuangan Lainnya. Ekonisia Kampus Fakultas Ekonomi UII.

Pandia, F. (2014). Manajemen Dana dan Kesehatan Bank. Rineka Cipta.

Sugiyono. (2017). Metode Penelitian Kunatitatif Kualitatif dan R\&D. Alfabeta.

Suhardjono. (2016). Manajemen Perkreditan Usaha Kecil dan Menengah. UPP, AMP YPKN. 